\title{
TO THE PROBLEM OF ENVIRONMENTAL EVALUATION OF THE CONDITIONS FOR THE GROWTH OF AGRICULTURAL CULTURES
}

\section{Kharchenko Oleg ${ }^{1}$ Petrenko Sergey $^{2}$}

\section{DOI: https://doi.org/10.30525/978-9934-571-89-3_111}

Formulation of the problem. Reforming land relations in the countryside and especially in the conditions of possible formation of the market of arable land, the problem of preserving their fertility becomes of particular importance [1, p. 34]. Currently, there is no doubt that the criteria for assessing the environmental safety of soils is the creation of conditions for the lack of deficit of the humus balance and the main elements of nutrition. These indicators are interdependent, but formally, not always positive conditions for one indicator predict positive for others. In terms of strategic assessment, in our opinion, the priority should be given to the balance of the main elements of nutrition, the lack of which can be one of the conditions for the lack of deficit of the humus balance.

Analysis of recent research and publications. Currently, there is no doubt that the growing and constant updating of new, more productive varieties and hybrids of agricultural crops requires consideration of the quantitative impact on their productivity norms fertilizer because it substantially differ from previously studied varieties and hybrids value as payback fertilizer use rate as key elements. Such an approach requires a quantitative assessment of their intensity in terms of the use of basic resources, especially mineral nutrition $[4$, p. $6 ; 5$, p. 7].

The level of productivity established by any method, or the accepted value requires an environmental justification, one of the criteria of which is to ensure the lack of deficit of the balance of the main elements of the supply. There is no doubt that this condition is obligatory, since one of the basic laws of agriculture corresponds to the "law of the return of nutrients to the soil". In this case, there is a need to take into account the problem, the essence of which is that any increase and stimulation of the productivity of the culture is accompanied by an adequate removal of the main elements with the harvest, which is far from always consistent with the norm of the fertilizer. No less important problem in this case should be considered and the balance of mineral fertilizers by the main elements of nutrition [4, p. 30; 5, p. 13].

It should be noted that the existing recommendations on the use of mineral fertilizers take into account the qualitative yield of the alienated products of the main elements of food, but this is not consistent with the reaction of culture to the crop in the established norms [2, p. 21].

In addition, existing scientific developments [3, p. 9; 4, p. 34] on the one hand allow to determine the required rate of mineral fertilizers only when planning, and on

\footnotetext{
${ }^{1}$ Sumy National Agrarian University, Ukraine

${ }^{2}$ Sumy National Agrarian University, Ukraine
} 
the other - do not take into account the necessary conditions for lack of deficit of the main elements of nutrition.

The purpose of this study is to establish normative conditions for ensuring the lack of deficit of the main elements at the planning stage and to assess the actual state of the results of the cultivation of some new hybrids of maize under the conditions of the NAIHIA for 2017-2018.

Presenting main material. In assessing the influence of the factor of the variety on the indicators of intensification of cultivation, it is necessary to determine the indicators of its intensity, or yields of this variety. In general, this indicator represents the level of intensity of the variety (RiC) and can be established as the ratio of actual (UV) to the possible, or normative (UN) values of the yield of culture [4, p. 6; 5, p. 11]:

$$
\operatorname{RiC}=\frac{y_{\phi}}{y_{H}}
$$

Thus, he shows how many times the actual crop yield of this variety is greater than the yield that can be determined or calculated according to the existing normative data.

In the case when the efficiency of mineral fertilizers is determined by the law of declining yield $[3$, p. $9 ; 4$, p. 20] the total normative yield of a crop can be expressed in dependence:

$$
y_{H}=a X^{2}+b X+y_{5}, u / 2 a
$$

where: $a$ and $b$-empirical coefficients [3, p. 17; 4, p. 18];

$y_{5}$-productivity, which is formed due to the natural fertility of soils [3, p. 17].

Based on dependencies 1 and 2, we can state that the actual expected yield of a crop can be established as:

$$
y_{\Phi}=R i C \cdot y_{H}=R i C\left(y_{5}+\Delta y_{\text {म }}\right)=R i C \cdot y_{5}+R i C \cdot \Delta y_{\text {д }}, u / 2 a .
$$

The basic elements (X1, cd.r. /c) with the crop yield (Y, c/ha) are defined as:

$$
X_{1}=y \cdot \Sigma B_{M}, u \partial \cdot p \cdot / z a
$$

where: - the total content of the main elements of food in the alienated product, cd.r./ha.

Thus, the comparison of the dependence of the reaction of the culture on the fertilizer (formula 3 ) and the removal of the main elements with the yield (formula 4), allows us to establish a fertilizer norm (equivalent), which will ensure a deficit-free balance of the main elements from the condition [4, p. 34; 5, p. 13]:

$$
-a \cdot R i C \cdot X^{2}+\left(b \cdot R i C-\frac{1}{\sum B M}\right) X+R i C \cdot y_{B}=0
$$

The work evaluates the results of cultivating some maize hybrids under environmental constraints and compares them with the basic requirements. 
In our case, on the black earths of the typical regressed medium loamy ones, according to the existing recommendations, we have [3, p. 9; 4, p. 17]:

$$
y_{\bar{b}}=49,3 u / 2 a ; \Delta y=-0,97 X^{2}+9,27 X, u / 2 a
$$

The results of calculations for establishing the main environmental parameters for some maize hybrids are given in Table. 1

Table 1

Parameters of the deficit-free balance of N P K for some maize hybrids and comparison with actual data

\begin{tabular}{|c|c|c|c|c|c|c|}
\hline \multirow{2}{*}{ Hybrids } & \multirow{2}{*}{ FAO } & \multirow{2}{*}{ RiC } & \multicolumn{2}{|c|}{ Actual data } & \multicolumn{2}{c|}{ Recommended data } \\
\cline { 4 - 7 } & & & HF, kg / ha & UV, c / ha & HE, kg / ha & Ue, c / ha \\
\hline Star & 180 & 1,36 & 190 & 86,1 & 242 & 89,2 \\
\hline Stork & 260 & 1,42 & 190 & 90,1 & 254 & 94,6 \\
\hline Donor & 310 & 1,53 & 190 & 97,2 & 279 & 103,4 \\
\hline
\end{tabular}

The analysis of the data showed that the later the hybrids, the more efficient the use of power resources, the greater the yield. The analysis of experimental data showed that in all cultivar variants a basic nutrient deficiency (NPK) is formed, which, depending on FAO, is $52-89 \mathrm{~kg} / \mathrm{ha}$. At the same time, for the equivalent fertilizer norm, the expected increase in yield would be 3.1-3.6 c/ha. There is no doubt that such a statement requires an economic substantiation, but in each case there is a need to choose a priority option.

It has been proved that ensuring the conditions of non -deficiency in the soil of the main elements of nutrition is necessary to take into account the level of intensity of specific varieties or hybrids of agricultural crops.

\section{References:}

1. Balyuk S.A., Medvedev V.V., Miroshnichenko M.M. (2016). Natsional'na prohrama zakhystu hruntiv [National Soil Protection Program]. Ukrainian Chernozem. Volume 1. P. 34-48.

2. Balyuk S.A., Forest M.V. (2013). Metodychni rekomendatsiyi dlya rozrakhunku potreb mineral'nykh dobryv dlya prohnozovanoho valovoho zboru, skoryhovani za faktychnymy pohodnymy ta klimatychnymy umovamy potochnoho roku [Methodical recommendations for calculating the needs of mineral fertilizers for the forecast gross harvest, corrected for actual weather and climatic conditions of the current year]. ed. S.A. Balyuk and M.V. Forest Kharkiv, 35 p.

3. Kalinchik M.V., Il'chuk M.M. (2006). Ekonomichne obgruntuvannya norm zastosuvannya mineral'nykh dobryv zalezhno vid tsiny resursiv i produktiv [Economic substantiation of the norms of mineral fertilizer application depending on the price of resources and products]. K.: Nichlava, 43 p.

4. Kharchenko O.V., Prasol V.I., Kabanets V.V. (2017). Ahroekonomichni ta ekolohichni aspekty vstanovlennya optymal'noho rivnya urozhaynosti novykh sortiv sil's'kohospodars'kykh kul'tur [Agro-economic and ecological aspects of establishing the optimum level of yield of new varieties of agricultural crops]. Sumy: FOP Scherbina, $151 \mathrm{p}$.

5. Kharchenko O.V., Prasol V.I., Zakharchenko E.A., Petrenko Y.M., Sobko M.G. (2016). Pro problemu analitychnoyi otsinky efektyvnosti mineral'nykh dobryv ta ekolohichnykh obmezhen' norm [On the problem of analytical evaluation of the efficiency of mineral fertilizers and environmental restrictions of norms]. Sumy: University book. $32 \mathrm{p}$. 